\title{
Chemical Constituents and Antifungal Activity of Leaf Essential Oil from Oreopanax ecuadorensis Seem. (Pumamaki), Endemic Plant of Ecuador
}

\author{
Paco Noriega ${ }^{1, *}$, Bryan Vergara $^{1}$, Carlos Carillo ${ }^{2}$, Tatiana Mosquera ${ }^{2}$
}

Paco Noriega ${ }^{1, *}$, Bryan Vergara', Carlos Carillo², Tatiana Mosquera ${ }^{2}$

'Group of Research and Development in Sciences Applied to Biological Resources, Universidad Politécnica Salesiana, Avenida 12 de Octubre N 2422 y Wilson, Quito, ECUADOR.

${ }^{2}$ Group of Research in Apply Biotechnology to the Natural Resources, Universidad Politécnica Salesiana, Avenida 12 de Octubre N 2422 y Wilson, Quito, ECUADOR.

\section{Correspondence}

\section{Paco Noriega}

Group of Research and Development in Sciences Applied to Biological Resources, Universidad Politécnica Salesiana, Avenida 12 de Octubre N 2422 y Wilson, Quito, ECUADOR.

E-mail: pnoriega@ups.edu.ec

History

- Submission Date: 09-09-2019

- Review completed: 11-09-2019;

- Accepted Date: 19-09-2019.

DOI : 10.5530/pj.2019.11.236

Article Available online

http://www.phcogj.com/v11/i6s

\section{Copyright}

(C) 2019 Phcogj.Com. This is an openaccess article distributed under the terms of the Creative Commons Attribution 4.0 International license.

\begin{abstract}
Background: Oreopanax ecuadorensis Seem. is a plant from Ecuador, that is found in the Andean region of the country. The plant is commonly used in protective rituals, and as an antiflu, analgesic and disinfectant medicine. Aim: The research aims to extract and analyze the chemical composition and evaluation of its antifungal potential of the essential oil extracted from its leaves. Methods: steam distillation was used for the extraction of essential oil, the evaluation of its components was performed by GC/MS, and the antifungal evaluation by the disc diffusion method. Results: The essential oil was obtained with a yield of $0.05 \%$. 33 compounds were detected of which 30 were identified, corresponding to $99.28 \%$; the most abundant molecules were: thujene $\langle\alpha->(36.63 \%)$, followed by bicyclogermacrene with $(8.76 \%)$, pinene $<\beta$ - > with (8.32\%) and limonene with $5.15 \%$. Three of the four strains evaluated were affected by the oil at concentrations of $1.25 \%$, inhibiting its growth. The strains were: Trichophyton mentagrophytes, Trichophyton rubrum and Microsporum canis. Conclusion: The essential oil shows good antifungal activity, which could be less than $1.25 \%$. In this way, this medicinal plant is valued by verifying ancestral knowledge in the use of medicinal plants by the Andean people of Ecuador.

Key words: Oreopanax ecuadorensis, Puma Maki, Antifungal activity, GC/MS
\end{abstract}

\section{INTRODUCTION}

"Pumamaky", Oreopanax ecuadorensis Seem., is an endemic medicinal species from Ecuador. ${ }^{1}$ It is characteristic of the Andean forests, and is generally found between 2500 and 3600 meters above sea level, ${ }^{2-4}$ it is common to find it in most of the provinces of the Ecuadorian highlands. ${ }^{1}$

O. ecuadorensis belongs to the Araliaceae family, it is a tree or shrub that reaches 10 meters high and $50 \mathrm{~cm}$ in diameter. ${ }^{5}$ Its leaves have a characteristic shape similar to that of an animal paw, which gives rise to the traditional Quichua name of the species, which in Spanish means puma hand.

Pumamaky is considered by the Quichua people as a sacred plant, ${ }^{6}$ among its most prominent medicinal uses we have: protective and purifying baths, ${ }^{6,7}$ postpartum baths, ${ }^{7,8}$ colds $^{7}$ and headaches. ${ }^{9}$ Traditional uses not described in the scientific literature show its ability to disinfect wounds caused by pathogenic fungi of the skin, for this reason a study is proposed that can verify the antifungal potential against dermatophytes, using the essential oils extracted from its leaves, because several species of the Araliaceae family, which contain essential oils, have proven effective as antifungal. ${ }^{10-12}$

Despite being a medicinal plant frequently used by the ancestral peoples of Ecuador, there are no studies on chemistry and biological activity in the species, therefore this research is an important starting point and opens the possibility of knowing more on the pharmaceutical potential of $O$. ecuadorensis.

\section{MATERIALS AND METHODS}

\section{Plant materials}

The plant material was collected in the Quero canton, province of Tungurahua, at the following coordinates: Latitude of $13^{\circ} 30^{\prime} 00$ "S, longitude of 78 ${ }^{\circ} 37^{\prime} 00^{\prime \prime} \mathrm{W}$ and altitude of 2760 m.a.s.l. The botanical identification of the species was in charge of botanist Alvaro Pérez of the herbarium of the Pontificia Universidad Católica of Ecuador. 60 kilograms of O. ecuadorensis leaves were collected. Subsequently, the oil was extracted from the fresh leaves in a 64-liter stainless steel distiller installed in the Life Sciences Laboratories of the Universidad Politécnica Salesiana, which operates through the water and water vapor mechanism. ${ }^{13}$ Time of distillation was three ours.

Gas chromatography-mass spectroscopy analysis (GC-MS)

Essential oils were analyzed using GC-MS. The analysis was done with a Varian 3900 gas chromatograph equipped with a Factor Four column VF-5ms 5\%-phenyl-95\%-dimethylpolysiloxane (internal diameter of $30 \mathrm{~m} \times 0,25 \mathrm{~mm}, 0,25 \mu \mathrm{m}$ film thickness) and directly interfaced to a Varian Saturn 2100 mass spectrometer. The carrier gas was helio $(1 \mathrm{~mL} / \mathrm{min})$ with a split ratio of 1:50. The oven temperature was initially $45{ }^{\circ} \mathrm{C}$ and then raised to

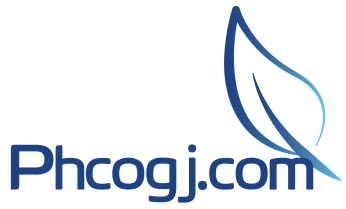

Cite this article: Noriega P, Vergara B, Carillo C, Mosquera T. Chemical Constituents and Antifungal Activity of Leaf Essential Oil from Oreopanax ecuadorensis Seem. (Pumamaki), Endemic Plant of Ecuador. Pharmacog J. 2019;11(6)Suppl:1544-8. 
$100{ }^{\circ} \mathrm{C}$ at a rate of $1{ }^{\circ} \mathrm{C} / \mathrm{min}$, then raised to $250^{\circ} \mathrm{C}$ at a rate of $5{ }^{\circ} \mathrm{C} /$ $\mathrm{min}$, and finally held at that temperature for $15 \mathrm{~min}$. The MS conditions were as follows: ionization voltage, $70 \mathrm{eV}$; emission current, $10 \mu \mathrm{Amp}$; scan rate, $1 \mathrm{scan} / \mathrm{min}$; mass range, $35-400 \mathrm{Da}$; trap temperature, $220^{\circ} \mathrm{C}$; transfer line temperature, $260^{\circ} \mathrm{C}$.

\section{Determination of essential oil composition}

The identification of compounds was achieved by comparing the mass spectra against commercial NIST 2001 MS library. The experimental calculation of retention indexes was determined in relation to retention times from a series of $\mathrm{n}$-alkanes (C10-C30); and the theoretical retention indexes was compared to Adams databases for aromatic molecules. ${ }^{14}$

\section{Antifungal activity}

The technique employed for the determination of antifungal activity was that of disc diffusion, which has been used in a large number of tests with essential oils. ${ }^{15-17}$

Due to the fact that the plant is used in dermal pathologies, the potential of the essential oil in strains related to skin diseases was evaluated: Trichophyton mentagrophytes ATCC 9533, Trichophyton rubrum ATCC 28188, Microsporum canis ATCC 36299 and Candida albicans ATCC 10231. Various concentrations of the essential oil dissolved in dimethylsulfoxide (DMSO) were evaluated, ranging from 5 to $1.25 \%$. Clotrimazole was used as a positive control.

\section{RESULTS AND DISCUSSION}

\section{Essential oil}

The yield of the essential oil was $0.5 \mathrm{~mL}$ per kilogram of fresh plant, with a yield of $0.05 \%$. A total of 33 compounds were detected, of which 30 were identified, representing $99.28 \%$. The most abundant molecule was thujene $\langle\alpha->$ with $36.63 \%$, followed by bicyclogermacrene with $8.76 \%$, pinene $<\beta->$ with $8.32 \%$ and limonene with $5.15 \%$. Table 1 shows the composition of the essential oil of $O$. ecuadorensis.

We found monoterpene hydrocarbons and sesquiterpene hydrocarbons in greater quantity representing $96.93 \%$, the amount of oxygenated compounds is very low.

\section{Antifungal activity}

With the exception of Candida albicans, the essential oil was active in the concentration ranges between $5 \%$ and $1.25 \%$. Inhibition halos were measured in millimeters, with positive results of activity being those whose halos are greater than $6 \mathrm{~mm}$. The results of this test can be seen in full in Table 2.

Table 1: Chemical composition of the essential oil from the leaves of 0 . ecuadorensis.

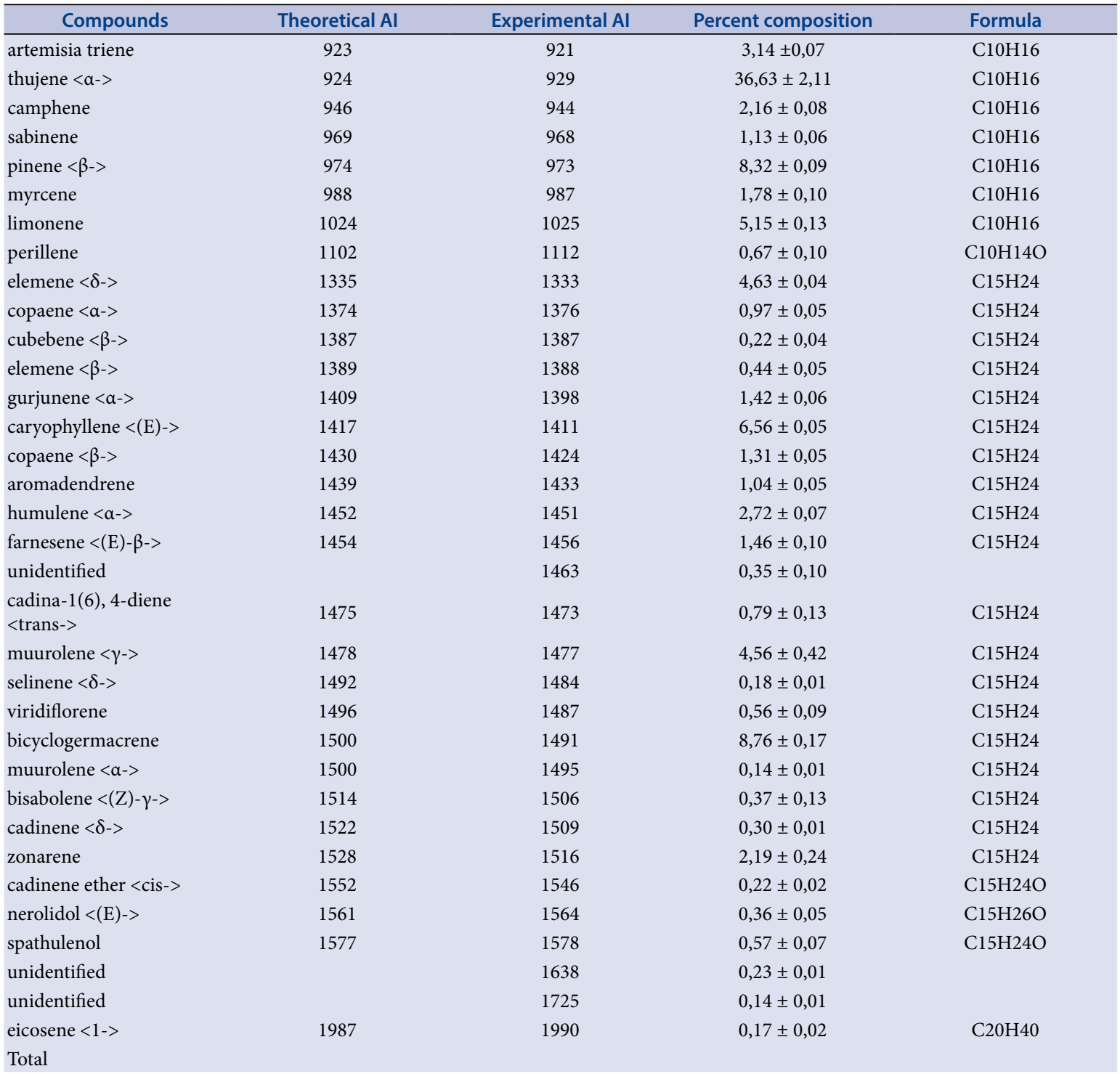




\begin{tabular}{lc} 
Monoterpene hydrocarbons & 58,31 \\
Oxygenated monoterpenes & 0,67 \\
Sesquiterpene hydrocarbons & 38,62 \\
Oxygenated Sesquiterpenes & 1,15 \\
Others & 0,17 \\
Unidentified & 0,72 \\
\hline
\end{tabular}

Table 2: Growth of inhibition of various fungi exposed to the essential oil from O. ecuadorensis.

\begin{tabular}{|c|c|c|c|c|}
\hline \multirow{2}{*}{$\begin{array}{c}\text { Essential oil } \\
\text { concentration of } \mathrm{O} \text {. } \\
\text { ecuadorensis }\end{array}$} & \multicolumn{4}{|c|}{ Average halos of inhibition in millimeters } \\
\hline & C. albicans & T. mentagrophytes & T. rubrum & M. canis \\
\hline $5 \%$ & $6.0 \pm 0.0$ & $13.23 \pm 1.93$ & $11.83 \pm 1.58$ & $13.77 \pm 1.62$ \\
\hline $2.5 \%$ & $6.0 \pm 0.0$ & $8.40 \pm 0.93$ & $10.82 \pm 1.57$ & $13.31 \pm 1.23$ \\
\hline $1.25 \%$ & $6.0 \pm 0.0$ & $6.14 \pm 0.09$ & $8.84 \pm 1.26$ & $10.97 \pm 0.57$ \\
\hline
\end{tabular}

The results observed for the strains, T. rubrum and M. canis, indicate that the activity would continue to occur at concentrations below $1.25 \%$, which leads us to presume values of minimum inhibitory concentration, resulting in this value.

\section{CONCLUSIONS}

The most abundant molecule was thujene $\langle\alpha->$, a hydrocarbon monoterpene, followed by bicyclogermacrene, pinene $\langle\beta->$ and limonene. The most abundant compounds are hydrocarbon monoterpenes with formula $\mathrm{C}_{10} \mathrm{H}_{15}$. Some species rich in thujene $<\alpha$ $>$, such as Eucalyptus alba, have been shown to have high antifungal activity. ${ }^{18}$ Similarly, both pinene $\langle\beta->$ and limonene are molecules whose antifungal potential is proven. ${ }^{19-20}$

Through this study the antifungal potential of the species is confirmed, therefore the ancestral medicinal use of the species by the inhabitants of the Ecuadorian Andes is valued.

\section{CONFLICTS OF INTEREST}

The authors declare that they have no conflicts of interest to disclose.

\section{ABBREVIATIONS}

GC/MS: Gas chromatography Mass Spectrometry; O. ecuadorensis: Oreopanax ecuadorensis; C. albicans: Candida albicans; T. mentagrophytes: Trichophyton mentagrophytes; T. rubrum: Trichophyton rubrum; M. canis: Microsporum canis.

\section{REFERENCES}

1. Jorgensen PM, Leon-Yanez S. Catálogo de las plantas vasculares del Ecuador. Missouri Botanical Garden. St. Louis; 1999.

2. Peñafiel M, Tipán M, Nolivos L, Vásquez K. Biological diversity in Cotacachi's Andean forests. Development with Identity: Community, Culture and Sustainability in the Andes. CABI Publishing. Oxfordshire; 2006.

3. Curipoma S, Cevallos D, Pérez ÁJ. Composición y estructura florística de dos remanentes de Bosque Andino Montano Alto en el volcán llaló, Ecuador. Revista Ecuatoriana de Medicina y Ciencias Biológicas. 2018;39(2).

4. Franco W, Peñafiel M, Cerón C, Freire E. Biodiversidad productiva y asociada en el Valle Interandino Norte del Ecuador. Bioagro. 2016;28(3).
5. Borchsenius F. Oreopanax (Araliaceae) in Ecuador. Nord J Bot. 1997;17(4):373 96.

6. Noriega Rivera PF, Chicaiza Taco TA. La Flora Medicinal de los Parques de Distrito Metropolitano de Quito. Editorial Abya-Yala. Quito; 2018.

7. Cerón Martínez CE. Plantas medicinales de los Andes Ecuatorianos. Botánica Económica de los Andes Centrales. 2006:285-96.

8. Dávila M, Pomboza P, Vásquez C, GómezT. Etnobotánica de Plantas Nativas de una Comunidad Rural de la Sierra, Ecuador: un análisis cuantitativo. Arnaldoa. 2016;23(1):219-34

9. Tene V, Malagon O, Vita Finzi P, Vidari G, Armijos C, ZaragozaT. An ethnobotanica survey of medicinal plants used in Loja and Zamora-Chinchipe, Ecuador. J Ethnopharmacol. 2007;111(1):63-81.

10. Hu H, Zheng $X, H u H$, Li Y. Chemical compositions and antimicrobial activities of essential oils extracted from Acanthopanax brachypus. Arch Phar Res. 2009;32(5):699-710.

11. Sabulal B, George V, Pradeep NS, Dan M. Volatile oils from the root, stem and leaves of Schefflera stellata (Gaertn.) Harms (Araliaceae): Chemical characterization and antimicrobial activity. J Essent Oil Res. 2008;20(1):79-82.

12. $\mathrm{Hu} \mathrm{H}$, Zheng $\mathrm{X}, \mathrm{Hu} \mathrm{H}$. Chemical composition, antimicrobial, antioxidant and cytotoxic activity of the essential oil from the leaves of Acanthopanax leucorrhizus (Oliv.) Harms. Environ Toxicol Phar. 2012;34(2):618-23.

13. Noriega P. Extracción, química, actividad biológica, control de calidad y potencial económico de los aceites esenciales. La Granja Revista de Ciencias de la Vida. 2009; 10(2):3-15

14. Adams RP. Identification of essential oil components by gas chromatography/ mass spectrometry. Allured Publishing Corporation. Carol Stream, IL; 2007.

15. Sharifi-Rad J, Hoseini-Alfatemi SM, Sharifi-Rad M, Setzer WN. Chemical composition, antifungal and antibacterial activities of essential oil from $L$ allemantia Royleana (B enth. in W all.) B enth. J Food Safety. 2015;35(1):19-25.

16. Kacem N, Roumy V, Duhal N, Merouane F, Neut C, Christen P, et al. Chemical composition of the essential oil from Algerian Genista quadriflora Munby and determination of its antibacterial and antifungal activities. Ind Crop Prod. 2016;90:87-93

17. Moghaddam M, Taheri P, Pirbalouti AG, Mehdizadeh L. Chemical composition and antifungal activity of essential oil from the seed of Echinophora platyloba DC. against phytopathogens fungi by two different screening methods. LWTFood Sci Technol. 2015;61(2):536-42.

18. Oyedeji AO, Ekundayo O, Olawore ON, Adeniyi BA, Koenig WA. Antimicrobial activity of the essential oils of five Eucalyptus species growing in Nigeria. Fitoterapia. 1999;70(5):526-8.

19. Krauze-Baranowska M, Mardarowicz M, Wiwart M, Pobłocka L, Dynowska M Antifungal activity of the essential oils from some species of the genus Pinus. Z. Naturforsch. C. 2002;57(5-6):478-82.

20. Chee $\mathrm{HY}, \mathrm{Mm} \mathrm{H}$, Lee $\mathrm{MH}$. In vitro antifungal activity of limonene against Trichophyton rubrum. Mycobiology. 2009;37(3):243-6. 


\section{GRAPHICAL ABSTRACT}
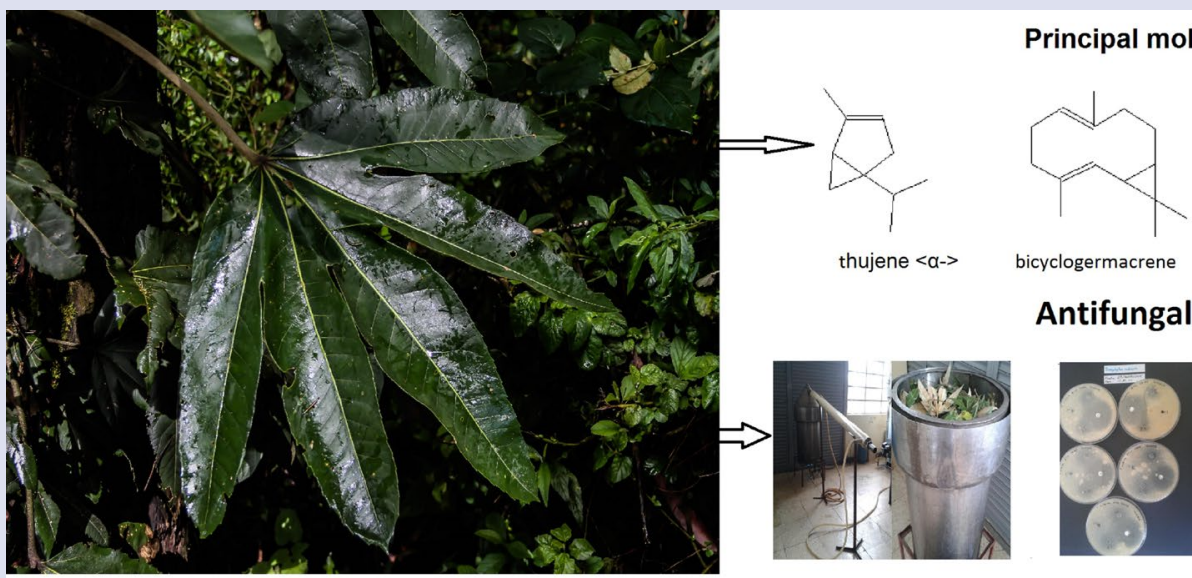

thujene $<\alpha->$

bicyclogermacrene

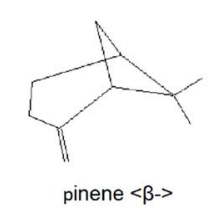

Antifungal activity
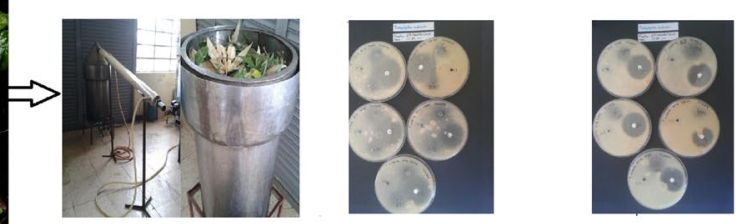

\section{Oreopanax ecuadorensis Seeman (Pumamaki) essential oil, molecules and antifungal activity}

\section{SUMMARY}

- $O$. ecuadorensis is a sacred medicinal plant of the Andean peoples of Ecuador, used for the treatment of various ailments and diseases, including for the disinfection of wounds.

- The extracted essential oil had a yield of $0.05 \%$ Using the GC/MS technique, 30 compounds in the essential oil were identified, corresponding to $99.28 \%$. The most abundant component was thujene $<\alpha->$ with $36.63 \%$.

- In the range of concentrations between 5 and $1.25 \%$, the oil is active in 3 of the 4 evaluated strains. Activity is observed against: T. mentagrophytes, T. rubrum and $M$. canis.

\section{ABOUT AUTHORS}

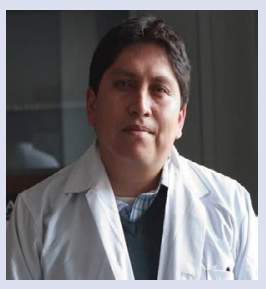

Paco Noriega:

University degree in Chemistry

Master's degree in biological research

PhD degree in Pharmaceutical Science

Full Professor and researcher in Salesian Polytechnic University, in the chairs of: Organic chemistry,

Pharmacognosy and Spectroscopy.

Author of 30 papers, 3 books and chapters books.

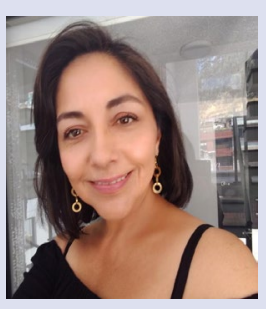

\section{Tatiana Mosquera:}

University degree in Biochemistry

Master's degree in science of cosmetics

Full Profesor and researcher in Salesian Polytechnic University, in the chairs of: Phamaceutical Tecnology. Author of 10 papers and 1 books.

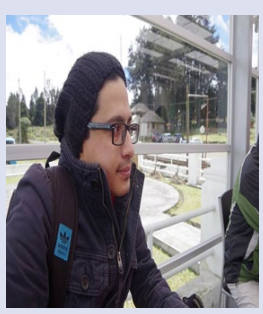

\section{Carlos Carillo:}

University degree in Biotechnology. 


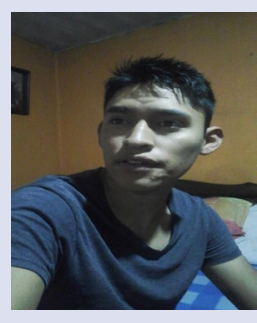

Bryan Vergara:

University degree in Biotechnology.

Cite this article: Noriega P, Vergara B, Carillo C, Mosquera T. Chemical Constituents and Antifungal Activity of Leaf Essential Oil from Oreopanax ecuadorensis Seem. (Pumamaki), Endemic Plant of Ecuador. Pharmacog J. 2019;11(6)Suppl:1544-8. 